\title{
Plant species richness or soil fertility: which affects more the productivity of Scots pine in Central Europe?
}

\author{
Piotr Sewerniak
}

Sewerniak P., 2020. Plant species richness or soil fertility: which affects more the productivity of Scots pine in Central Europe? Ann. For. Res. 63(2): 57-73.

Abstract It has been highlighted that forest productivity is related both to species richness and to soil fertility; however, thus far it has not been investigated which of these agents is more important for the productivity. The goal of this study was to examine this problem with regard to Scots pine (Pinus sylvestris L.) stands in Central Europe. The study was conducted in 129 plots located in SW Poland. The productivity of even-aged pine stands was estimated based on site index. Plant species richness was investigated regarding the total richness as well as the richness referring to particular forest strata (overstorey, understorey, herb layer). Soil fertility was studied regarding the nutrients' stocks, the contents of fine-textural classes, $\mathrm{pH}$, the TOC content and the values of Soil Trophic Index. The importance of the variables for the site index was examined using Spearman correlations and the stepwise regression. Productivity of the studied stands was predominantly correlated stronger to species richness than to soil properties being related to its fertility. The higher importance for the productivity of soil variables than of species richness was exclusively found for the poorest plots being represented by Podzols. This study highlights the high importance of species richness occurring in particular forest strata for the forest stand productivity, which could involve consequences for forest economy as well as for $\mathrm{CO}_{2}$ sequestration. Thus, the research delivers strong argument for the conversion of pine mono-stands occurring in Central Europe for mixed forests.

Keywords: pine stand, soil conditions, species richness, vertical forest strata, forest conversion

Address: Department of Soil Science and Landscape Management, Nicolaus Copernicus University in Torun, Poland.

¿ Corresponding Author: Piotr Sewerniak (sewern@umk.pl).

Manuscript received August 31, 2020; revised December 15, 2020; accepted December 22, 2020. 


\section{Introduction}

Forest productivity is one of the fundamental issues for forestry. It determines the volume of wood production, which is essential for the global society. Besides, in recent decades the importance of the effective forest productivity has been also highlighted with regard to the carbon sequestration, which is crucial to mitigate the ongoing climate change, and is more efficient in forest stands of high than of low both productivity (Bellassen \& Luyssaert 2014) and species richness (Caspersen \& Pacala 2001). Thus, forest productivity is the key issue both from the economic as well as from the ecological point of view. Consequently, the productivity as well as its controlling agents have been extensively discussed in scientific papers (e.g., Lasota et al. 2016, Liang et al. 2016, Li et al. 2018). However, it has been highlighted that many the underlying mechanisms which control the forest productivity are still not fully understood (Ammer 2018), which is essential to be examined both for science and practice (Pretzsch et al. 2015).

The most commonly used and widely accepted method of evaluating the forest productivity is site index (SI) (Skovsgaard \& Vanclay 2008, Sharma et al. 2011, Socha \& Orzeł 2013, Socha et al. 2016). Following the occurrence of the well-known strict relation between the stem-wood production in forest stands and the dominant tree height (e.g., Nilsson et al. 2012), the index is used both to estimate forest potential productivity (Skovsgaard \& Vanclay 2008) as well as to gauge forest stand productivity (Socha 2012, Eckhart et al. 2019). To minimalize the effect of forest management on the SI values, the index is calculated based on the top stand height, which is usually understood as the height of the 100 thickest trees per hectare (Sharma et al. 2002, Socha 2008, Socha et al. 2016). The measured in the field height is subsequently recalculated using species-specific models for the potential stand height at the base age, which is usually set at some age less than the anticipated rotation age (Goelz \& Burk 1996, Sharma et al. 2002). With reference to pine stands of Central Europe, SI is commonly computed for the base age of 100 years (Socha \& Orzeł 2013, Socha et al. 2016).

In the traditional approach, the natural factors affecting forest productivity have been linked to the geocentric agents, which include climatic and soil characteristics, mainly (Hägglund \& Lundmark 1977, Lasota et al. 2016). The effect of climate was highlighted to be crucial for affecting forest productivity in general comparisons across species and regions, while for a given species within a growth region climatic variable only give a rough estimate of the productivity (Skovsgaard \& Vanclay 2008). Consequently, in the geocentric approach, soil characteristics are usually primarily considered when forest productivity is linked to its natural controls in a particular region (Brożek et al. 2008, Lasota et al. 2016). Specifically, nutrients levels and soil texture are predominantly linked to site productivity (Marques 1991, Brożek et al. 2008, Lasota et al. 2016). With reference to Central European Scots pine (Pinus sylvestris L.) ecosystems, it was found that among nutritional elements the stand productivity defined with Scots pine SI was the strongest positively correlated to soil stocks of potassium and magnesium as well as to the content of nitrogen in a humus (A) horizon (Sewerniak 2012b). While regarding textural fractions the productivity was strongly, positively related to contents of fine fractions; however, the relation was the strongest not for the finest studied fraction $(<0.02 \mathrm{~mm})$, but for the fraction 0.02 $0.1 \mathrm{~mm}$ (Sewerniak 2011). It was also revealed that the effects of soil properties being related to fertility on Scots pine productivity varied in the gradient of soil moisture (Sewerniak 2011, 2012a, b). Acidification is also highlighted to be the essential factor affecting the forest productivity. Usually, the adverse effect of 
decreasing soil $\mathrm{pH}$ on the tree growth has been reported (Kidd \& Proctor 2001, Jönsson et al. 2003, Zhang et al. 2016), which is linked to the release of aluminum to soil solution in strongly acidified environment, and its subsequent toxic impact on tree roots (Jönsson et al. 2003, Gruba 2004, Zhang et al. 2016). On the other hand, for some environments the opposite relation was found; namely, low $\mathrm{pH}$ was positively related to biomass production in tropical forest ecosystems (Fujii 2014). This was also revealed with regard to European Scots pine woodlands, in which the significant negative correlation was found between SI and soil pH (Sewerniak 2012a).

Recent studies have highlighted that reducing natural factors controlling forest productivity to the effects of climate and of soil characteristics is controversial. Namely, in some current research the clear positive relation between species richness and the productivity of forest ecosystems was found. For example, such relation was revealed with regard to global forests by Zhang et al. (2012) as well as by Liang et al. (2016), and in Canadian woodlands investigated by Zhang et al. (2017). Besides, the positive relationship between species richness and aboveground plant biomass was also found in Pinus kesiya Royle ex Gordon forests in China ( $\mathrm{Li}$ et al. 2018). However, thus far such a study has not been conducted with regard to Scots pine, which has the widest natural distribution of any pine species in Europe (Kelly \& Conolly 2000, Leuschner \& Ellenberg 2017), and overgrows also extensive areas in Northern Asia (Zhu et al. 2003). The positive effect of the species richness on forest productivity has been usually highlighted based on research in which overstorey was included while the richness occurring in understorey as well as in herb layer was usually neglected. Thus, in many studies the beneficial effect of mixed tree species composition on forest productivity has been reported (Bielak et al. 2014, 2015, Pretzsch et al. 2015, Forrester \& Bauhus
2016), while the research which additionally include also lower forest strata in the analysis are relatively scarce (Zhang et al. 2017, Li et al. 2018).

Despite the fact that the clear relations between soil properties and forest productivity have been known for many decades, and that in recent studies the essential effect of species richness for the productivity has been additionally revealed, the forest productivity controlling agents remain still not fully described and understood (Ammer 2018, Sheil \& Bongers 2020). Additionally, to date it has not been arbitrated if the importance of soil fertility or of species richness is more significant for the productivity. Besides, thus far the effects of these agents (soil fertility and species richness) on the productivity of Scots pine dominated stands have been only roughly described in literature, albeit such forests overgrow extensive areas in the world (Kelly \& Conolly 2000, Zhu et al. 2003, Leuschner $\&$ Ellenberg 2017). Thus, the aim of this study was to examine the relationships between SI of Scots pine stands and 1) soil properties being related to fertility (nutrients, $\mathrm{TOC}, \mathrm{pH}$, contents of fine textural classes) as well as 2) species richness, and to test the importance of these two factors (soil fertility and species richness) for the productivity. Following the recent results which highlighted the essential significance of the species richness for forest productivity (Zhang et al. 2012, Liang et al. 2016, Li et al. 2018), it was hypothesized that the importance of this factor could be more important than of the soil fertility for the Scots pine stands' productivity in Central Europe.

\section{Material and methods}

\section{Study sites and sampling}

The study was conducted in 129 plots situated in three Forest Districts (Bolesławiec, Głogów and Oława) located in SW Poland (Fig. 1). 


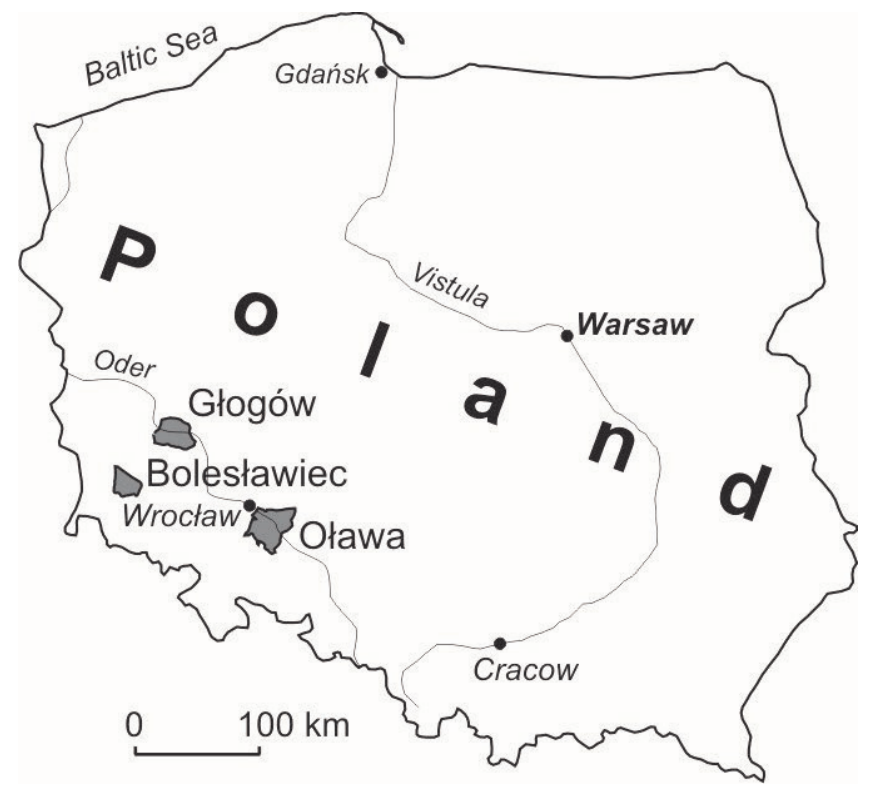

Figure 1 Location of the investigated Forest Districts

Following the fact that fine-textured soils are usually much more fertile than those of sandy texture (Pritchett 1979), forests overgrow usually sandy areas while woodlands occurring on fine-textured soils are relatively scarce in the studied region. Majority of the region had been primarily overgrown with deciduous or mixed forests which referred also to most of areas covered with sand (Olaczek 1976). However, since the turn of 18th and 19th century Scots pine monocultures were artificially introduced (usually by planting) in extensive areas in Central Europe, usually with no regard to soil fertility or to species composition of primary, potential vegetation (Olaczek 1976, Zerbe 2002, Spiecker 2003). It happens that in such pine mono-stands broadleaved species of trees and shrubs encroach by natural succession or are introduced by planting due to forest conversion. Thus, consequently in some studied pine dominated stands an admixture of deciduous species occurred, which particularly referred to the second tree layer of overstorey and to understorey.

All the studied plots were located within a maximum distance of ca. $150 \mathrm{~km}$, thus the climatic conditions were similar in each plot. The studied region is characterized by transitional climate, between oceanic and continental. The mean annual temperature is $8.7^{\circ} \mathrm{C}$, with monthly averages ranged from 0.6 to $18.7^{\circ} \mathrm{C}$ (in January and July, respectively). The mean annual precipitation is $551 \mathrm{~mm}$, with July being the wettest month (Siedliskowe 2004).

Each studied plot was located in a production evenaged Scots pine stand in which the mean share of the species in overstorey was $94 \%$. The admixture of broadleaved species in overstorey main layer occurred in 62 investigated stands, and, on average, it equaled in the stands $12 \%$. The main admixture tree taxa were Quercus petraea (Matt.) Liebl., Q. robur L., Fagus sylvatica L., and Betula pendula Roth. The mean age of the studied stands was 87 years, and the age range was between 42 and 132 years. In preliminary works of this study, forest areas in which pine growth was significantly affected by non-pedological agents (industrial impacts, pest outbreaks, fires, etc.) were excluded from the research. Furthermore, during the field stage of the study post-agricultural woodlands were also excluded based on the verification of a ploughing humus (A) horizon occurrence in the soil profile. This was done because the previous agricultural usage of a soil affects growth dynamics of a forest stand as well as species composition of vegetation (Flinn \& Marks 2007, von Oheimb et al. 2014), and consequently could obliterate the relations investigated in this study. The soil in each plot was classified in field regarding the soil unit according to World Reference Base (IUSS Working Group WRB 2015).

In each plot, species composition of all vascular plants was determined, which was 
done separately for all forest vertical strata occurring in a plot. Specifically, vegetation within each plot was classified as either part of overstorey, understorey or herb layer. Additionally, overstorey and understorey was investigated regarding two strata. Namely, the upper and the second storey were distinguished in overstorey, while understorey was investigated separately with regard to tree and shrub species. Following the different plant growth forms, the area for determination of species richness was different for particular forest strata. It was 0.3 hectare for overstorey and understorey, while it was $400 \mathrm{~m}^{2}$ for herb layer. In such areas all occurring plant species were recorded and ordered to particular forest strata. Finally, based on the survey conducted, the total number of plant species occurring in all the strata was determined for every plot which was treated as the total plant species richness of a plot.

In each plot the height of the 10 thickest pines were measured in 0.1 hectare, and subsequently from these measurements the mean height was calculated for a plot. Such height is commonly considered as the top height of a stand, which is recommended for the calculation of SI (Sharma et al. 2002, Socha \& Orzeł 2013, Socha et al. 2016). The heights of pines were measured in a field using an optical Suunto altimeter.

\section{Data analysis}

The results were analyzed jointly in the whole set containing all the 129 studied plots; however, additionally the results were examined separately in two groups varying in site moisture. This was done because site moisture had a strong effect on growth of pine stands in Central Europe, and the moisture agent affected the existed relations between pine SI and soil properties (Sewerniak 2011, 2012a, b, Sewerniak \& Piernik 2012). Thus, it was assumed that the relationship between species richness and Scots pine productivity could also differ in the two moisture groups. Consequently, the study was conducted regarding plots of lower soil moisture (92 plots, hereafter referred as "dry plots", DP), and higher soil moisture (37 plots, hereafter referred as "moist plots", MP). The criterion of ordering the plot to a group was the occurrence of the ground water table and/or the clear gleyic properties within a soil profile. The existence of at least one of these attributes involved classification of a plot as MP.

The mean numbers of plant species by forest strata in the investigated plots' sets were shown in Table 1.

Table 1 Mean number $( \pm \mathrm{SD})$ of plant species by forest strata in the investigated plots' sets

\begin{tabular}{|c|c|c|c|c|}
\hline \multicolumn{2}{|l|}{ Forest strata } & \multirow{2}{*}{$\begin{array}{r}\text { All plots } \\
2.0 \pm 1.2\end{array}$} & \multirow{2}{*}{$\begin{array}{r}\text { Dry plots } \\
1.9 \pm 1.3\end{array}$} & \multirow{2}{*}{$\frac{\text { Moist plots }}{2.2 \pm 1.2}$} \\
\hline & Upper layer & & & \\
\hline \multirow[t]{3}{*}{ Overstorey } & Second layer & $1.9 \pm 1.5$ & $1.7 \pm 1.5$ & $2.3 \pm 1.5$ \\
\hline & All species in a stratum & $3.3 \pm 1.5$ & $3.2 \pm 1.6$ & $3.7 \pm 1.3$ \\
\hline & Trees & $2.1 \pm 1.3$ & $2.0 \pm 1.2$ & $\overline{2.4 \pm 1.5}$ \\
\hline \multirow[t]{2}{*}{ Understorey } & Shrubs & $1.8 \pm 1.4$ & $1.7 \pm 1.4$ & $1.9 \pm 1.3$ \\
\hline & All species in a stratum & $3.8 \pm 2.1$ & $4.5 \pm 2.0$ & $4.2 \pm 2.5$ \\
\hline \multicolumn{2}{|c|}{ All woody plants (over- and understorey) } & $6.2 \pm 2.5$ & $6.0 \pm 2.5$ & $6.6 \pm 2.5$ \\
\hline \multicolumn{2}{|l|}{ Herb layer } & $7.9 \pm 4.7$ & $7.3 \pm 4.1$ & $9.6 \pm 5.6$ \\
\hline \multicolumn{2}{|c|}{ Total plant species richness } & $14.0 \pm 6.5$ & $13.2 \pm 5.8$ & $16.1 \pm 7.8$ \\
\hline
\end{tabular}


Each soil analyzed in this study had a detail specification regarding its properties in Forest Inventory Data (Operat 2003, 2004, 2005). From these resources for this study the following soil properties being related to soil fertility were extracted: content of total organic carbon (TOC) by the wet dichromate oxidation method, content of total nitrogen $(\mathrm{Nt})$ by the Kjeldahl method, $\mathrm{C}: \mathrm{N}$ ratio in humus (A) horizon, $\mathrm{pH}$ of soil-to-solution ratio of 1:2.5 using $1 \mathrm{M} \mathrm{KCl}$ as the suspension medium, contents of exchangeable basic nutritional cations $\left(\mathrm{Ca}^{2+}, \mathrm{Mg}^{2+}, \mathrm{K}^{+}\right)$after extraction with 1 $\mathrm{M}$ ammonium acetate at $\mathrm{pH} 7.0$, by a SOLAAR 699 atomic absorption spectrophotometer, and contents of fine textural fractions $(<0.002$, 0.005-0.002, 0.02-0.005, 0.05-0.02, 0.1-0.05 $\mathrm{mm}$ ) by the hydrometer method. Records on TOC and Nt was available for humus (A) horizon only, while those on other properties were available by horizons for soil profiles. Thus, to more easily compare the investigated plots as well as to include whole soil profiles in the analyses, one value concerning each variable (except for TOC, $\mathrm{Nt}$, and $\mathrm{C}: \mathrm{N}$ ) was calculated for a single plot. Specifically, regarding $\mathrm{Ca}^{2+}, \mathrm{Mg}^{2+}$ and $\mathrm{K}^{+}$, stocks of each cation were calculated to the equal for each plot soil mineral layer of $0-150 \mathrm{~cm}$. It was done based on cations' contents in particular soil horizons, bulk density and the thickness of the horizons. The 0-150 cm stock of each element was obtained as a sum of stocks calculated for all horizons occurring to the depth of $150 \mathrm{~cm}$. Using thicknesses of soil mineral horizons and specific analytical records stated for each horizon, the weight average values (hereafter referred as Indices - I) of $\mathrm{pH}$ as well as of particular textural classes were calculated for each soil. Regarding $\mathrm{pH}$, raw values measured in humus horizon and in soil parent material was additionally investigated in the study. In the analyses, $\mathrm{pH}$ records measured in potassium chloride were employed, because they showed stronger correlation to SI of Scots pine stands than those detected in water
(Sewerniak 2012a).

Based on pedological characteristics found for each soil, the value of Soil Trophic Index (STI) was calculated for each plot. The index was elaborated by Brożek et al. (2008) based on studies conducted in 200 forest plots located throughout Poland. The following soil characteristics were employed to obtain values of STI: content of the $<0.02 \mathrm{~mm}$ textural fraction, total content of basic cations $\left(\mathrm{Ca}^{2+}\right.$, $\left.\mathrm{Mg}^{2+}, \mathrm{K}^{+}, \mathrm{Na}^{+}\right)$, total content of acidic cations $\left(\mathrm{Al}^{3+}, \mathrm{H}^{+}\right)$, bulk density and thicknesses of soil horizons. The variables were considered by soil horizons to the $0-150 \mathrm{~cm}$ soil layer. Besides, content of TOC and Nt in a topsoil was included in the Index. The detailed procedure of processing soil data to obtain STI for the recommended 0-150 cm layer was described in the paper of Brożek at al. (2008). The mean values of the investigated soil properties as well as the STI values by the investigated plots' sets were shown in Table 2 .

Additionally, the study was conducted regarding soil units. However, only three most numerous WRB units representing the investigated plots were included in this part of the study. The units were Brunic Arenosols (in German "Sand-Braunerde", in Polish "gleby rdzawe"; according to Soil Taxonomy (Soil Survey Staff 2014) referred as "Typic Udipsamments" (Kabała et al. 2019), Podzols and Luvisols (51, 30 and 24 plots, respectively). Some Brunic Arenosols in which sandy material was underlaid by finetextured deposits were excluded from this part of the study. This was done because Brunic Arenosols are typically sandy soils (IUSS Working Group WRB 2015). Thus, including in the analysis pedons having fine-textured underline would distort the results obtained with reference to this soil unit, because finetextured material usually significantly affects the original nutritional status of sandy soils (Pritchett 1979). Mean species richness by forest strata regarding the investigated soil units was presented in Table 3, while mean 
records on soil characteristics were shown in Table 4. The detailed characteristics both of records related to a forest stand as well as to soil characteristics by the studied plots were illustrated in online Supplementary Information 1.

Table 2 Mean values $( \pm \mathrm{SD})$ of related to fertility soil characteristics as well as mean Soil Trophic Index (STI) values in the studied plots by the investigated plots' sets

\begin{tabular}{llrrr}
\hline Soil characteristics & & All plots & Dry plots & Moist plots \\
\hline & $\mathrm{Ca}^{2+}$ & $106 \pm 142$ & $105 \pm 154$ & $113 \pm 110$ \\
Stocks 0-150 cm [cmol $\left.\mathrm{kg}^{-1}\right]$ & $\mathrm{Mg}^{2+}$ & $42.8 \pm 71.6$ & $41.5 \pm 69.2$ & $46.0 \pm 78.1$ \\
& $\mathrm{~K}^{+}$ & $11.2 \pm 7.7$ & $10.9 \pm 6.6$ & $12.1 \pm 10.0$ \\
\hline $\mathrm{TOC}\left[\mathrm{g} \mathrm{kg}^{-1}\right]$ content in A horizon & & $20.2 \pm 17.7$ & $20.4 \pm 18.3$ & $19.6 \pm 16.1$ \\
$\mathrm{~N}\left[\mathrm{~g} \mathrm{~kg}^{-1}\right.$ c content in A horizon & & $0.70 \pm 0.45$ & $0.64 \pm 0.33$ & $0.91 \pm 0.67$ \\
$\mathrm{C}: \mathrm{N}$ in A horizon & & $23.6 \pm 7.8$ & $22.7 \pm 6.4$ & $26.3 \pm 10.9$ \\
\hline & in A horizon & $3.2 \pm 0.4$ & $3.3 \pm 0.4$ & $3.2 \pm 0.4$ \\
$\mathrm{pH}$ & in parent material & $4.4 \pm 0.9$ & $4.5 \pm 0.9$ & $4.3 \pm 0.6$ \\
& $\mathrm{I}_{\mathrm{pH}}$ & $4.2 \pm 0.6$ & $4.3 \pm 0.6$ & $4.1 \pm 0.5$ \\
\hline & $\mathrm{I}_{0.1-0.05 \mathrm{~mm}}$ & $7.1 \pm 5.9$ & $7.4 \pm 6.6$ & $6.3 \pm 3.9$ \\
& $\mathrm{I}_{0.05-0.02 \mathrm{~mm}}$ & $5.6 \pm 7.1$ & $6.0 \pm 8.1$ & $4.5 \pm 3.5$ \\
Weight average content of a textural & $\mathrm{I}_{0.02-0.005 \mathrm{~mm}}$ & $3.3 \pm 3.1$ & $3.2 \pm 3.0$ & $3.6 \pm 3.3$ \\
fraction [\%] & $\mathrm{I}_{0.005-0.002 \mathrm{~mm}}$ & $1.8 \pm 1.7$ & $1.7 \pm 1.6$ & $2.1 \pm 2.0$ \\
& $\mathrm{I}_{<0.002 \mathrm{~mm}}$ & $4.0 \pm 7.3$ & $3.5 \pm 6.2$ & $5.4 \pm 9.5$ \\
\hline Soil Trophic Index (STI) & & $20.7 \pm 7.4$ & $20.4 \pm 7.7$ & $21.4 \pm 6.6$ \\
\hline
\end{tabular}

Table 3 Mean number $( \pm \mathrm{SD})$ of plant species by forest strata in the studied soil units

\begin{tabular}{|c|c|c|c|c|}
\hline \multicolumn{2}{|l|}{ Forest strata } & \multirow{2}{*}{$\begin{array}{r}\text { Brunic Arenosols } \\
1.8 \pm 1.2\end{array}$} & \multirow{2}{*}{$\begin{array}{r}\text { Podzols } \\
1.6 \pm 0.8\end{array}$} & \multirow{2}{*}{$\begin{array}{r}\text { Luvisols } \\
2.8 \pm 1.6\end{array}$} \\
\hline & Upper layer & & & \\
\hline \multirow[t]{3}{*}{ Overstorey } & Second layer & $1.5 \pm 1.3$ & $1.7 \pm 1.3$ & $2.6 \pm 1.5$ \\
\hline & All species in a stratum & $2.9 \pm 1.4$ & $2.8 \pm 1.2$ & $4.4 \pm 1.4$ \\
\hline & Trees & $2.2 \pm 1.2$ & $1.7 \pm 1.1$ & $2.1 \pm 1.3$ \\
\hline \multirow[t]{2}{*}{ Understorey } & Shrubs & $1.6 \pm 1.5$ & $1.3 \pm 0.9$ & $2.3 \pm 1.3$ \\
\hline & All species in a stratum & $3.7 \pm 2.1$ & $2.9 \pm 1.5$ & $4.4 \pm 1.6$ \\
\hline \multicolumn{2}{|c|}{ All woody plants (over- and understorey) } & $5.9 \pm 2.6$ & $5.1 \pm 1.6$ & $7.4 \pm 1.9$ \\
\hline \multicolumn{2}{|c|}{ Herb layer } & $7.6 \pm 4.2$ & $5.6 \pm 2.6$ & $10.4 \pm 3.9$ \\
\hline \multicolumn{2}{|c|}{ Total plant species richness } & $13.4 \pm 5.9$ & $10.5 \pm 3.4$ & $17.8 \pm 4.9$ \\
\hline
\end{tabular}

Based on the top height of each pine stand the value of SI was calculated for each plot. This was done using the dynamic model elaborated by Socha and Orzeł (2013) for pine stands of southern Poland:

$$
\mathrm{SI}=\mathrm{H}_{1} \frac{729.76 \times\left(\mathrm{T}_{1}^{1.4316} \times \mathrm{R}+14325.1\right)}{\mathrm{T}_{1}^{1.4316} \times(729.76 \times \mathrm{R}+14325.1)}
$$

where $\mathrm{H}_{1}$ is the height at the age $\mathrm{T}_{1}, \mathrm{~T}_{1}$ is the age and $\mathrm{R}$ is calculated as follows (Socha \& Orzeł 2013):

$$
+\sqrt{\mathrm{R}=2.2937+\mathrm{H}_{1}+} \frac{}{\left(2.2937+\mathrm{H}_{1}\right)^{2}+2 \mathrm{H}_{1} \times 14325.1 / \mathrm{T}_{1}^{1.4316}}
$$


The obtained values of SI were negatively correlated to stand age $\left(\mathrm{R}^{2}=0.26, \mathrm{p}<\right.$ $0.05)$. Such relation between SI and age was commonly revealed in many previous studies (e.g., Socha 2008, Sewerniak 2011, 2016, Sharma et al. 2012, Socha et al. 2016). It is recommended to exclude the SI-age bias by adjusting the SI model to local site conditions by incorporating age trend (Socha et al. 2016). In this study, the bias was eliminated using a simple method proposed by Socha et al. (2016). Namely, the regression model was elaborated describing the relationship between residuals of the SI prediction model and the stand age; and the error in the predicted SI as a function of stand age was determined. Next, the SI of the stand at a given age was corrected by subtracting the correction factor calculated as the difference between the computed SI and the error obtained for the age from the regression model. Such procedure enabled removal of the age trend from SI model (Socha et al. 2016), which was relevant also to this study $\left(\mathrm{R}^{2}=9 \mathrm{e}-08\right)$.

Many of the investigated variables differed from the normal distribution ( $p$ values in the Shapiro-Wilk test $<0.05$ ). Hence, the Spearman's rank correlation was used to examine the relationships between the investigated variables. The importance of particular variables to the pine SI was additionally examined in the linear backward stepwise regression, which was commonly used to identify the best explanatory variables for tree productivity (Paquette \& Messier 2011). Due to some relations referring to the raw data were curvilinear, the log transformation of each variable was performed before the regression analyses. The results of this transformation are shown in online Supplementary Information 2. To reduce the number of independent variables included in the regression analyses, only six the variables were employed in each run. Specifically, for each plots' set variables for which the highest Spearman correlations were found were included. However, they were selected by one from each group of variables. Namely, the strongest correlated to SI variable related to species richness as well as the strongest correlated one representing nutrients $\left(\mathrm{Ca}^{2+}, \mathrm{Mg}^{2+}, \mathrm{K}^{+}, \mathrm{N}\right), \mathrm{pH}$ variables and textural fractions were employed.

Table 4 Mean values $( \pm \mathrm{SD})$ of soil characteristics as well as mean Soil Trophic Index (STI) in the studied plots by soil units

\begin{tabular}{llrrr}
\hline Soil characteristics & & Brunic Arenosols & Podzols & Luvisols \\
\hline \multirow{2}{*}{ Stocks 0-150 cm [cmol $\left.\mathrm{cg}^{-1}\right]$} & $\mathrm{Ca}^{2+}$ & $77.4 \pm 109$ & $47.5 \pm 24.7$ & $197 \pm 234$ \\
& $\mathrm{Mg}^{2+}$ & $20.0 \pm 24.9$ & $10.6 \pm 3.6$ & $95.8 \pm 111$ \\
& $\mathrm{~K}^{+}$ & $8.8 \pm 4.4$ & $8.1 \pm 6.2$ & $15.8 \pm 6.6$ \\
\hline TOC $\left[\mathrm{g} \mathrm{kg}^{-1}\right]$ content in A horizon & & $1.6 \pm 1.0$ & $1.5 \pm 0.9$ & $3.8 \pm 2.6$ \\
$\mathrm{~N}\left[\mathrm{~g} \mathrm{~kg}^{-1}\right]$ content in A horizon & & $0.07 \pm 0.04$ & $0.07 \pm 0.05$ & $0.11 \pm 0.08$ \\
$\mathrm{C}: \mathrm{N}$ in A horizon & & $22.0 \pm 6.5$ & $27.6 \pm 8.6$ & $20.4 \pm 4.1$ \\
\hline & in A horizon & $3.2 \pm 0.3$ & $3.1 \pm 0.4$ & $3.3 \pm 0.4$ \\
$\mathrm{pH}$ & in parent material & $4.2 \pm 0.4$ & $4.5 \pm 0.7$ & $4.4 \pm 1.1$ \\
& $\mathrm{I}_{\mathrm{pH}}$ & $4.2 \pm 0.3$ & $4.4 \pm 0.6$ & $4.0 \pm 0.4$ \\
\hline & $\mathrm{I}_{0.1-0.05 \mathrm{~mm}}$ & $6.0 \pm 6.1$ & $4.6 \pm 4.9$ & $11.1 \pm 4.4$ \\
Weight average content of a textural & $\mathrm{I}_{0.05-0.02 \mathrm{~mm}}$ & $3.7 \pm 5.8$ & $2.3 \pm 1.9$ & $12.8 \pm 10.4$ \\
fraction [\%] & $\mathrm{I}_{0.02-0.005 \mathrm{~mm}}$ & $1.7 \pm 1.5$ & $1.6 \pm 1.1$ & $7.1 \pm 2.8$ \\
& $\mathrm{I}_{0.005-0.002 \mathrm{~mm}}$ & $0.9 \pm 0.6$ & $1.0 \pm 0.9$ & $3.4 \pm 1.7$ \\
& $\mathrm{I}_{<0.002 \mathrm{~mm}}$ & $1.1 \pm 1.1$ & $1.3 \pm 1.5$ & $9.0 \pm 9.9$ \\
\hline Soil Trophic Index (STI) & & $17.4 \pm 5.8$ & $15.6 \pm 5.4$ & $29.5 \pm 3.5$ \\
\hline
\end{tabular}


Table 5 Spearman correlations between values of pine site index and the number of plant species by forest strata as well as the soil properties related to fertility and the values of Soil Trophic Index (STI). $* \mathrm{p}<0.05, * * \mathrm{p}<0.01, * * * \mathrm{p}<0.001$. In grey, the three strongest relations for each plots' set were marked

\begin{tabular}{|c|c|c|c|c|c|}
\hline Characteristics & & & All plots & Dry plots & Moist plots \\
\hline \multirow{9}{*}{$\begin{array}{l}\text { Number of } \\
\text { species }\end{array}$} & \multirow{3}{*}{ Overstorey } & Upper layer & $0.28 * *$ & $0.29 * *$ & 0.20 \\
\hline & & Second layer & $0.45 * * *$ & $0.51 * * *$ & 0.20 \\
\hline & & All species in a stratum & $0.55 * * *$ & $0.60 * * *$ & $0.37 *$ \\
\hline & \multirow{3}{*}{ Understorey } & Trees & 0.07 & -0.04 & 0.28 \\
\hline & & Shrubs & $0.41 * * *$ & $0.47 * * *$ & 0.24 \\
\hline & & All species in a stratum & $0.32 * * *$ & $0.30 * *$ & 0.32 \\
\hline & \multicolumn{2}{|c|}{ All woody plants (over- and understorey) } & $0.52 * * *$ & $0.58 * * *$ & 0.32 \\
\hline & \multicolumn{2}{|c|}{ Herb layer } & $0.54 * * *$ & $0.59 * * *$ & $0.36^{*}$ \\
\hline & \multicolumn{2}{|c|}{ Total plant species richness (all strata) } & $0.60 * * *$ & $0.66^{* * *}$ & $0.40 * *$ \\
\hline \multirow{15}{*}{ Soil properties } & \multirow{3}{*}{$\begin{array}{l}\text { Stocks } 0-150 \mathrm{~cm} \\
{\left[\mathrm{cmol}_{\mathrm{c}} \mathrm{kg}^{-1}\right]}\end{array}$} & $\mathrm{Ca}^{2+}$ & $0.30 * * *$ & $0.35 * * *$ & 0.04 \\
\hline & & $\mathrm{Mg}^{2+}$ & $0.42 * * *$ & $0.55^{* * *}$ & -0.01 \\
\hline & & $\mathrm{K}^{+}$ & $0.42 * * *$ & $0.53 * * *$ & 0.09 \\
\hline & \multicolumn{2}{|c|}{ TOC $\left[\mathrm{g} \mathrm{kg}^{-1}\right]$ content in A horizon } & 0.13 & $0.23^{*}$ & -0.1 \\
\hline & \multicolumn{2}{|c|}{$\mathrm{N}\left[\mathrm{g} \mathrm{kg}^{-1}\right]$ content in A horizon } & $0.36 * * *$ & $0.41 * * *$ & 0.20 \\
\hline & \multicolumn{2}{|l|}{$\mathrm{C}: \mathrm{N}$ in $\mathrm{A}$ horizon } & $-0.38 * * *$ & $-0.38 * * *$ & $-0.40 * *$ \\
\hline & \multirow{3}{*}{$\mathrm{pH}$} & in A horizon & -0.10 & -0.10 & -0.12 \\
\hline & & in parent material & $-0.34 * * *$ & $-0.46^{* * *}$ & -0.01 \\
\hline & & $\mathrm{I}_{\mathrm{pH}}$ & $-0.37 * * *$ & $-0.49 * * *$ & -0.02 \\
\hline & \multirow{5}{*}{$\begin{array}{l}\text { Weight average } \\
\text { content of a } \\
\text { textural fraction } \\
{[\%]}\end{array}$} & $\mathrm{I}_{0.1-0.05 \mathrm{~mm}}$ & $0.35^{* * *}$ & $0.51 * * *$ & -0.19 \\
\hline & & $\mathrm{I}_{0.05-0.02 \mathrm{~mm}}$ & $0.38 * * *$ & $0.52 * * *$ & 0.01 \\
\hline & & $\mathrm{I}_{0.02-0.005 \mathrm{~mm}}$ & $0.30 * * *$ & $0.36^{* * *}$ & 0.05 \\
\hline & & $\mathrm{I}_{0.005-0.002 \mathrm{~mm}}$ & $0.35 * * *$ & $0.39 * * *$ & 0.14 \\
\hline & & $\mathrm{I}_{<0.002 \mathrm{~mm}}$ & $0.22 *$ & $0.38 * * *$ & -0.19 \\
\hline & \multicolumn{2}{|c|}{ Soil Trophic Index (STI) } & $0.42 * * *$ & $0.52 * * *$ & 0.10 \\
\hline
\end{tabular}

In each regression analyses values of $\mathrm{C}: \mathrm{N}$ ratio as well as of STI were included. Thus, in each stepwise regression run, one variable being related to species richness and five variables referring to soil properties were employed (the strongest correlated to SI variable being related to 1 . nutrients, $2 . \mathrm{pH}$, 3. texture, and additionally 4 . C:N ratios and 5. STI values). The statistical analyses were conducted using the Statistica 9.0 software.

\section{Results}

\section{Analyses including all plots regardless of soil unit}

The Spearman correlation analysis conducted in the full set of 129 investigated plots revealed that SI was significantly related to almost all of the studied plant and pedological variables. The only exceptions were the number of tree species occurring in understorey, TOC content, and $\mathrm{pH}$ in $\mathrm{A}$ horizon, for which no statistical 
relation to SI was found (Table 5). Interestingly, the all three strongest relations were found for those related to species richness: primarily to the total plant species richness $(r=0.60)$, and subsequently to the number of species occurring in overstorey $(\mathrm{r}=0.55)$, and in herb layer $(\mathrm{r}=0.54$, Table 5). All these relations were of positive character, showing that higher species richness supports strongly the productivity of Scots pine stands. Most of the relations referring to soil characteristics were also positively related to SI. However, for all the variables being related to $\mathrm{pH}$ as well as for the value of $\mathrm{C}: \mathrm{N}$ ratio negative relationships were found (Table 5).

Some differences were revealed when the two studied soil moisture groups were separately investigated. The results obtained for DP were very similar to those detected for the whole plots' set, which did not, however, referred to MD. Namely, the only significant correlations regarding the latter group pertained the positive relationship between SI and the total plant species richness $(r=0.40)$, the number of species occurring in overstorey $(r=0.37)$ and in herb layer (0.36, Table 5). In turn, when soil characteristics were considered, only one variable was detected as significant for SI. It was $\mathrm{C}: \mathrm{N}$ ratio being negatively related to Scots pine productivity $(\mathrm{r}=-0.40$, Table 5$)$.

The results obtained in the stepwise backward regression also suggest higher importance of the species richness than of the soil properties being related to its fertility for SI. Namely, in a model elaborated for the full set of the investigated plots, the only variable left after the stepwise selection was the total plant species richness, and the model explained $42 \%$ of the total variance (Table 6). Higher variance explained (55\%) referred to a model computed for the set of DP. The variables finally included in the model were the total plant species richness and $\mathrm{I}_{\mathrm{pH}}$. However, the former variable was positively, while the latter negatively related to SI. In the analysis regarding MP, all employed variables were finally removed in the stepwise backward procedure from the model. However, the last variable being removed was referred to the species richness: it was the total number of plant species occurring in a plot.

Table 6 Results of the stepwise backward regression obtained for the studied plots' sets

\begin{tabular}{lllrr}
\hline & Variables left in a model & Model & $\mathrm{R}^{2}$ & $\mathrm{p}$ \\
\hline All plots & Total plant species richness (a) & $\mathrm{SI}=-0.39+0.65 \mathrm{a}$ & 0.42 & 0.0000 \\
Dry plots & Total plant species richness (a), $\mathrm{I}_{\mathrm{pH}}(\mathrm{b})$ & $\mathrm{SI}=1.43+0.51 \mathrm{a}-0.37 \mathrm{~b}$ & 0.55 & 0.0000 \\
\hline
\end{tabular}

\section{Analyses regarding soil units}

Clear differences between the importance of the studied variables for SI were found when the analyses were conducted with regard to soil units. Strong positive relation between species richness and SI were revealed for Brunic Arenosols. The highest correlations referred to the total species richness $(r=0.67)$, the number of species occurring in herb layer $(\mathrm{r}=0.64)$, and the total richness of woody plants $(r=0.63$, Table 7$)$. Most correlations found for pedological characteristics were also significant; however, they were weaker than those referred to the species richness variables. The strongest relations revealed for soil attributes were the negative effect of $\mathrm{C}: \mathrm{N}$ ratio on $\mathrm{SI}(\mathrm{r}=$ -0.48), and the positive relation regarding the weight average content of the $0.1-0.05 \mathrm{~mm}$ textural fraction $(\mathrm{r}=0.47)$ as well as the soil stocks of $\mathrm{Mg}^{2+}(\mathrm{r}=0.46$, Table 7). Interestingly, the positive relations between SI and the content of textural fractions decreased with decreasing fraction size (Table 7). Finally, for the smallest fraction $(<0.002 \mathrm{~mm})$ the relation becomes statistically insignificant $(p=0.27)$. 
Interestingly, contrary to Brunic Arenosols, in plots ordered to Podzols soil characteristics showed stronger than the species richness variables relationships to SI. This concerns especially the effect of $\mathrm{pH}$. Specifically, all the three variables referring to $\mathrm{pH}$ were strongly negatively correlated to SI (Table 7). The strongest relation regarding species richness referred to the number of species in overstorey; however, the relation resulted from the strong effect of the richness in the second overstorey strata $(r=0.49)$, while the relation between the richness in upper overstorey strata and SI was insignificant $(\mathrm{r}=-0.03$, Table 7$)$.

The weakest relations were detected with regard to the plots representing Luvisols. With reference to this soil unit, the only significant relation concerned the positive effect of species richness in upper overstorey strata on SI $(\mathrm{r}=0.42)$.

Table 7 Spearman correlations between values of the pine site index and the number of plant species by forest strata as well as the soil properties related to fertility and the values of Soil Trophic Index (STI) by soil units. ${ }^{*} \mathrm{p}<0.05, * * \mathrm{p}<0.01, * * * \mathrm{p}<0.001$. In grey the three strongest relations for each plots' set were marked (regarding Luvisols only one existing significant relation was indicated)

\begin{tabular}{|c|c|c|c|c|c|}
\hline Characteristics & & & Brunic Arenosols & Podzols & Luvisols \\
\hline \multirow{9}{*}{$\begin{array}{l}\text { Number of } \\
\text { species }\end{array}$} & \multirow{3}{*}{ Overstorey } & Upper layer & 0.19 & -0.03 & $0.42 *$ \\
\hline & & Second layer & $0.52 * * *$ & $0.49 * *$ & 0.23 \\
\hline & & All species in a stratum & $0.59 * * *$ & $0.50 * *$ & 0.31 \\
\hline & \multirow{3}{*}{ Understorey } & Trees & 0.12 & -0.27 & -0.08 \\
\hline & & Shrubs & $0.61 * * *$ & 0.27 & -0.07 \\
\hline & & All species in a stratum & $0.47 * * *$ & 0.02 & -0.11 \\
\hline & \multicolumn{2}{|c|}{ All woody plants (over- and understorey) } & $0.63^{* * *}$ & 0.33 & 0.19 \\
\hline & \multicolumn{2}{|c|}{ Herb layer } & $0.64 * * *$ & $0.37 *$ & 0.29 \\
\hline & \multicolumn{2}{|c|}{ Total plant species richness (all strata) } & $0.67 * * *$ & 0.18 & 0.23 \\
\hline \multirow{15}{*}{ Soil properties } & \multirow{3}{*}{$\begin{array}{l}\text { Stocks } 0-150 \\
\mathrm{~cm}\left[\mathrm{cmol}_{\mathrm{c}} \mathrm{kg}^{-1}\right]\end{array}$} & $\mathrm{Ca}^{2+}$ & 0.18 & 0.35 & 0.22 \\
\hline & & $\mathrm{Mg}^{2+}$ & $0.46^{* * *}$ & $0.46^{* *}$ & -0.13 \\
\hline & & $\mathrm{K}^{+}$ & $0.38 * *$ & $0.63 * * *$ & 0.17 \\
\hline & \multicolumn{2}{|c|}{ TOC $\left[\mathrm{g} \mathrm{kg}^{-1}\right]$ content in A horizon } & -0.05 & $0.46^{*}$ & -0.07 \\
\hline & \multicolumn{2}{|c|}{$\mathrm{N}\left[\mathrm{g} \mathrm{kg}^{-1}\right]$ content in A horizon } & $0.31^{*}$ & $0.53 * *$ & -0.02 \\
\hline & \multicolumn{2}{|l|}{$\mathrm{C}: \mathrm{N}$ in A horizon } & $-0.48 * * *$ & -0.22 & -0.15 \\
\hline & \multirow{3}{*}{$\mathrm{pH}$} & in A horizon & -0.03 & $-0.66 * * *$ & 0.08 \\
\hline & & in parent material & $-0.30 *$ & $-0.67 * * *$ & -0.05 \\
\hline & & $\mathrm{I}_{\mathrm{pH}}$ & $-0.41 * *$ & $-0.67 * * *$ & 0.13 \\
\hline & \multirow{5}{*}{$\begin{array}{l}\text { Weight average } \\
\text { content of a } \\
\text { textural fraction } \\
{[\%]}\end{array}$} & $\mathrm{I}_{0.1-0.05 \mathrm{~mm}}$ & $0.47 * * *$ & 0.20 & -0.19 \\
\hline & & $\mathrm{I}_{0.05-0.02 \mathrm{~mm}}$ & $0.37 * *$ & $0.48^{* *}$ & -0.16 \\
\hline & & $\mathrm{I}_{0.02-0.005 \mathrm{~mm}}$ & $0.29^{*}$ & $0.38^{*}$ & -0.39 \\
\hline & & $\mathrm{I}_{0.005-0.002 \mathrm{~mm}}$ & $0.34 *$ & $0.44 *$ & -0.08 \\
\hline & & $\mathrm{I}_{<0.002 \mathrm{~mm}}$ & 0.16 & $0.37^{*}$ & -0.23 \\
\hline & \multicolumn{2}{|c|}{ Soil Trophic Index (STI) } & 0.06 & $0.41 * *$ & 0.06 \\
\hline
\end{tabular}


The differences between soil units revealed in the correlation analysis were supported in the stepwise backward regression. In a model elaborated for Brunic Arenosols two variables were finally left: the total plant species richness as well as the weight average content of the 0.1$0.05 \mathrm{~mm}$ textural fraction, and the elaborated model explained $57 \%$ of the total variance. The higher variance explained (71\%) showed the model computed for Podzols. This reflected the strong importance of $\mathrm{pH}$ for SI in pine stands overgrowing these soils, because only one variable was left in the model after the stepwise backward selection, and it was $\mathrm{I}_{\mathrm{pH}}$ (Table 8). In turn, the relations pertaining Luvisols were not strong enough to elaborate any model with the stepwise backward regression, because finally all the variables were removed from the model. However, regarding this soil unit, the stepwise regression analysis suggested higher importance of species richness than of soil fertility for Scots pine productivity, because the number of species occurring in upper layer of overstorey was the last variable being removed from a model. managers, primarily by introducing tree species in a forest site as well as subsequent execution of thinnings. Thus, although the found in this study as well as in previous research (Zhang et al. 2012, Liang et al. 2016) positive relation between the tree species richness and forest productivity is crucial, for example, to encourage practical foresters to converse conifer monocultures into mixed forests, the relation does not give the full insight into the natural relation between plant species richness and forest productivity. In managed forest stands, the existence of this relation could be primarily proved when naturally encroaching plant species into forest stands are considered, which predominantly refers to herb layer. The revealed in this study strong positive relation between the number of plant species occurring in this layer and SI supports the based on the tree diversity positive relation between species richness and forest productivity (Zhang et al. 2012, Liang et al. 2016), which alone could potentially be implied by anthropogenic factor (intentional introducing tree species due to forest management).

Table 8 Results of the stepwise backward regression obtained for plots representing Brunic Arenosols and Podzols

\begin{tabular}{lllrr}
\hline & Variables left in a model & Model & $\mathrm{R}^{2}$ & $\mathrm{p}$ \\
\hline Brunic & Total plant species richness $(\mathrm{a})$, & $\mathrm{SI}=1.16+0.61 \mathrm{a}+0.33 \mathrm{~b}$ & 0.57 & 0.0000 \\
Arenosols & $\mathrm{I}_{0.1-0.05 \mathrm{~mm}}(\mathrm{~b})$ & $\mathrm{SI}=1.28-0.85 \mathrm{a}$ & 0.71 & 0.0000 \\
\hline
\end{tabular}

The underlying mechanisms of the relationship between plant diversity and forest stand productivity are still not fully understood;

\section{Discussion}

This study suggests that species richness is predominantly more important than soil fertility for Scots pine productivity in Central Europe. The positive relation between the number of species occurring in a forest stand and its productivity was highlighted in previous studies; albeit, it was usually revealed with regard to the species richness referring to tree diversity (Bielak et al. 2014, 2015, Pretzsch et al. 2015). However, the diversity occurring in tree layers is strongly affected by forest however, competition reduction and facilitation have been identified as key mechanisms driving the diversity-productivity relationship (Ammer 2018). It is highlighted that mixed compared with pure stands can improve the supply, capture, or use efficiency of resources and thereby increase productivity (Forrester 2014, 2015, Pretzsch et al. 2015). Besides, the rate of decomposition of the pure conifer litterfall is usually slower than the litterfall of mixed forest stands, which entails that the turnover of nutrients in a soil-vegetation system in the latter stands is quicker (Namikawa et al. 
2000). In turn, the efficient flux of nutrients between the ecosystem components is crucial for sustaining forest site productivity (Pritchett 1979, Wang et al. 2015). This can be linked to the found in this study clear negative relation between the productivity of pine stands and $\mathrm{C}: \mathrm{N}$ ratio in the topsoil. The ratio indicates the litter susceptibility to decomposition (Berg \& McClaugherty 2008), the smaller it is the faster the rate is and thus the nutrients' turnover in forest ecosystem is more efficient (Zhou et al. 2008, Jasińska et al. 2019). In this context, the results obtained in this study could be discussed regarding the real (usually introduced by foresters) vs potential vegetation occurring in the studied plots, including also subsequent consequences of this relation for sustainable forestry. Namely, although pine stands have been introduced in the studied sites by forest managers, the potential vegetation of extensive sandy areas in Central Europe is broadleaved or mixed forest (Zerbe 2002, Spiecker 2003, Kint et al. 2006), which refers also to the studied region (Olaczek 1976). This pertains not only fine-textured Luvisols, but also Brunic Arenosols, which are degraded by acidification and podzolization after overplanting with pure conifer stands (Augusto et al. 1998, Biały 1999, Jankowski 2014). In turn, the natural vegetation of Podzols occurring in Central Europe are woodlands dominated with conifers, thus the podzolization process cannot be understood as a degradation factor regarding this soil unit (IUSS Working Group WRB 2015). Thus, this study delivers strong argument supporting the idea to increase species richness in Central European woodlands by forest managers (Zerbe 2002, Pretzsch et al. 2010, Bielak et al. 2014, 2015, Pretzsch et al. 2015), which among the studied sandy soils pertains especially Brunic Arenosols. The research shows that the vital functioning of forest ecosystems being related to high plant biodiversity, and subsequently efficient nutrients' turnover can be more important for forest productivity than the soil fertility. In turn, relatively high site productivity could be not efficiently utilized in forestry if species composition is unified in forest management by introducing pure conifer monocultures.

The study shows also that the general higher importance of species richness than of soil fertility for forest productivity is not relevant when the poorest sites are considered, in which the opposite importance of these factors occurs. Specifically, this concerns Podzols being much poorer than both other studied soil units, which can be seen when nutrients' stocks as well as contents of fine textural classes are compared (Table 4). The revealed for Podzols negative relation between $\mathrm{pH}$ and pine productivity could be found controversial, because usually the adverse effect of low soil $\mathrm{pH}$ on the tree growth is highlighted (Kidd \& Proctor 2001, Jönsson et al. 2003, Zhang et al. 2016), which is linked to the toxic effect of aluminum in strongly acidic environments on tree roots (Jönsson et al. 2003, Gruba 2004, Zhang et al. 2016). However, the stated negative relation between $\mathrm{pH}$ and SI values could be explained first by the beneficial influence of low $\mathrm{pH}$ on pine ectomycorrhizal fungi, a large number of which have $\mathrm{pH}$ optima at ca. 3.0 (Finlay 1995). Secondly, the relation could be linked to the adaptation of Scots pine to grow on extremely poor soils. Namely, the efficiently produced in decomposing pine litter organic acids aggressively affect mineral soil grains, which stimulates weathering of minerals (Augusto et al. 2000). In turn, the latter process enables the release of nutrients from the minerals (Pritchett 1979, Augusto et al. 1998), which subsequently can be uptaken by roots, and thus the process of the increased weathering of a soil can mitigate nutrient depletion in pines. The negative relation between soil $\mathrm{pH}$ and forest productivity was also found with regard to other ecosystems (Fujii 2014).

This research suggests that in designation of pine monocultures for conversion in Central and Eastern Europe more attention 
should be directed to soil units. Despite the fact that Brunic Arenosols are characterized by much lower stocks of nutrients that finetextured Luvisols (Table 4), Scots pine stands overgrowing these soil units can have similar productivity (Sewerniak 2013). However, as it was figured out in this study the condition of the occurrence of such a comparable productivity regarding the units is that Brunic Arenosols are overgrown with vegetation of high diversity. In turn, the introduction on the soils of pure conifer stands involves their degradation (Biały 1999, Jankowski 2014), which subsequently decreases forest productivity (Sewerniak 2013). The results presented in this paper suggest that the conversion of mono conifer stands overgrowing Brunic Arenosols should be performed in more extensive area with regard to the occurrence of the soils than so far it has been executed. For example, in Polish forest management surveys, vast areas of the soils are still being dedicated for the introduction of the next generation of almost pure pine stand, which is done according to the operative forest instruction (Klasyfikacja 2000). This practice involves not only that site productivity is not fully utilized in forestry and soil degradation is progressing, but it also increases forest susceptibility to hazards. Namely, it has been broadly highlighted that pure conifer monocultures are much more exposed for disturbances such as fires, pest outbreaks and windthrows than broadleaved or mixed forests (Kenk \& Guehne 2001, Schelhaas et al. 2003, Spiecker 2003, Sierota el al. 2019). Thus, this study encourages to convert pine monocultures overgrowing Brunic Arenosols into mixed forests, which could be done, for example, by common underplanting the young and mid-aged monocultures being previously introduced on such soils with broadleaved species. The problem of rational management of forest stands overgrowing Brunic Arenosols is urgent and crucial, because the soils cover extensive areas in Central European lowlands (e.g., MLUV 2005, Systematyka 2019).
Besides, the frequency of forest huge damages has been increased in last decades (Gregow et al. 2017), and the ongoing climate change is predicted to might cause severe loss in the economic value of European forests in the future (Hanewinkel et al. 2013).

\section{Acknowledgments}

This work was supported by the Polish Ministry of Science and Higher Education (grant number N309 007 32/1037). The author thanks Sławomir Jaskólski for improving the English text.

\section{References}

Ammer C., 2018. Diversity and forest productivity in a changing climate. New Phytologist 221: 50-66. https:// doi: $10.1111 / \mathrm{nph} .15263$

Augusto L., Bonnaud P., Ranger J., 1998. Impact of tree species on forest soil acidification. Forest Ecology and Management 105: 67-78. https://doi.org/10.1016/ S0378-1127(97)00270-3

Augusto L., Turpault M-P., Ranger P., 2000. Impact of forest tree species on feldspar weathering rates. Geoderma 96: 215-237. https://doi.org/10.1016/S00167061(00)00021-5

Bellassen V., Luyssaert S., 2014. Carbon sequestration: Managing forests in uncertain times. Nature 506: 153156. https://doi: 10.1038/506153a

Berg B., McClaugherty C., 2008. Plant litter, decomposition, humus formation, carbon sequestration. Second ed. Springer, Heidelberg.

Biały K., 1999. Optionality in discrimination of forest site types and planning final species compositions in stands on podzolic soils. Sylwan 143: 65-72.

Bielak K., Dudzińska M., Pretzsch H., 2014. Mixed stands of Scots pine (Pinus sylvestris L.) and Norway spruce [Picea abies (L.) Karst] can be more productive than monocultures. Evidence from over 100 years of observation of long-term experiments. Forest Systems 23: 573-589. https://doi:10.5424/fs/2014233-06195

Bielak K., Dudzińska M., Pretzsch H., 2015. Volume growth of mixed-species versus pure stands: results from selected long-term experimental plots in Central Europe. Sylwan 159: 22-35. https://doi.org/10.26202/ sylwan.2014028

Brożek S., Zwydak M., Lasota J., 2008. Numerical index of trophic variants of Podzols and Arenosols subtypes. Rocz. Glebozn. 54: 7-17.

Caspersen J.P., Pacala S.W., 2001. Successional diversity and forest ecosystem function. Ecological Research 16: 895-903. https://doi.org/10.1046/j.14401703.2001.00455.x 
Eckhart T., Pötzelsberger E., Koeck R., Thom D., Lair G.J., van Loo M., Hasenauer H., 2019. Forest stand productivity derived from site conditions: an assessment of old Douglas-fir stands (Pseudotsuga menziesii (Mirb.) Franco var. menziesii) in Central Europe. Annals of Forest Science 76: 19. https://doi. org/10.1007/s13595-019-0805-3

Finlay R.D., 1995. Interactions between soil acidification, plant growth and nutrient uptake in ectomycorrhizal associations of forest trees. Ecological Bulletin 44: 197214. https://www.jstor.org/stable/20113163

Flinn K.M., Marks P.L., 2007. Agricultural legacies in forest environments: tree communities, soil properties, and light availability. Ecollogical Applications 17: 452463. https://doi: 10.1890/05-1963

Forrester D.I., 2014. The spatial and temporal dynamics of species interactions in mixed-species forests: from pattern to process. Forest Ecology and Management 312: 282-292. https://doi.org/10.1016/j.foreco.2013.10.003

Forrester D.I., 2015. Transpiration and water-use efficiency in mixed species forests versus monocultures: effects of tree size, stand density and season. Tree Physiology 35 : 289-304. https: //doi: 10.1093/treephys/tpv011

Forrester D.I., Bauhus J., 2016. A review of processes behind diversity-productivity relationships in forests. Current Forestry Reports 2: 45-61. https://doi: 10.1007/ s40725-016-0031-2

Fujii K., 2014. Soil acidification and adaptations of plants and microorganisms in Bornean tropical forests. Ecological Research 29: 371-381. https://doi: 10.1007/ s11284-014-1144-3

Goelz J.C.G., Burk T.E., 1996. Measurement error causes bias in site index equations. Canadian Journal of Forest Research 26: 1585-1593. https://doi.org/10.1139/x26-178

Gregow H., Laaksonen A., Alper M.E., 2017. Increasing large scale windstorm damage in Western, Central and Northern European forests, 1951-2010. Scientific Reports 7,46397. https://doi: 10.1038/srep46397.

Gruba P., 2004. Aluminium toxicity in forest soils. Sylwan, 148: 50-56. https://doi.org/10.26202/sylwan.2003907

Hägglund B., Lundmark J.E., 1977. Site index estimation by means of site properties Scots pine and Norway spruce in Sweden. Studia forestalia Suecica 138: 5-38.

Hanewinkel M., Cullmann D.A., Schelhaas M-J., Nabuurs G-J., Zimmermann N.E., 2013. Climate change may cause severe loss in the economic value of European forest land. Nature Climate Change 3: 203-207. https:// DOI: $10.1038 /$ nclimate 1687

IUSS Working Group WRB, 2015. World reference base for soil resources 2014 (Update 2015). International soil classification system for naming soils and creating legends for soil maps. World Soil Resources Reports No. 106. FAO, Rome.

Jankowski M., 2014. Bielicowanie jako wtórny process w glebach rdzawych Brodnickiego Parku Krajobrazowego [Podzolization as a secondary process in the rusty soils of the Brodnica Landscape Park]. In Świtoniak M, Jankowski M, Bednarek R (eds), Antropogeniczne przekształcenia pokrywy glebowej Brodnickiego Parku Krajobrazowego [Anthropogenic transformations of the soil cover of the Brodnica Landscape Park]. Wydawnictwo Naukowe UMK, Toruń, pp. 9-24.

Jasińska J., Sewerniak P., Markiewicz M., 2019. Links between slope aspect and rate of litter decomposition on inland dunes. Catena 172: 501-508. https://doi. org/10.1016/j.catena.2018.09.025

Jönsson U., Rosengren U., Thelin G., Nihlgård B., 2003. Acidification-induced chemical changes in coniferous forest soils in southern Sweden 19881999. Environmental Pollution 123: 75-83. https://doi. org/10.1016/S0269-7491(02)00335-4

Kabała C., Charzyński P., Chodorowski J., Drewnik M., Glina B., Greinert A. et al., 2019. Polish soil classification, 6th edition - principles, classification scheme and correlations. Soil Science Annual 70: 7197. https://doi: 10.2478/ssa-2019-0009 http://karnet. up.wroc.pl/ kabala/SGP6_Soils.html

Kelly D.L., Conolly A., 2000. A review of the plant communities associated with Scots pine (Pinus sylvestris L.) in Europe, and an evaluation of putative indicator/specialist species. Investigación Agraria, Sistemas y Recursos Forestales, Serie 1:15-39. https:// doi: $10.5424 / 674$

Kenk G., Guehne S., 2001. Management of transformation in central Europe. Forest Ecology and Management 151: 107-119. https://doi.org/10.1016/S0378-1127(00)00701-5

Kidd P.S., Proctor J., 2001. Why plants grow poorly on very acid soils: are ecologists missing the obvious? Journal of Experimental Botany 52: 791-799. https:// doi.org/10.1093/jexbot/52.357.791

Kint V., Geudens G., Mohren G.M.J., Lust N., 2006. Silvicultural interpretation of natural vegetation dynamics in ageing Scots pine stands for their conversion into mixed broadleaved stands. Forest Ecology and Management 223: 363-370. https://doi. org/10.1016/j. foreco.2005.11.018

Klasyfikacja gleb leśnych Polski [Classification of forest soils in Poland]. Centrum Informacyjne Lasów Państwowych, Warszawa, 119 p.

Lasota J., Błońska E., Zwydak M., 2016. Relations between site characteristics and spruce stand productivity. Baltic Forestry 22: 81-89.

Leuschner C., Ellenberg H., 2017. Ecology of Central European forests. Vegetation ecology of Central Europe. Volume I. Springer International Publishing, Switzerland.

Li S., Su J., Lang X., Liu W., Ou G., 2018. Positive relationship between species richness and aboveground biomass across forest strata in a primary Pinus kesiya forest. Scientific Reports 8: 2227. https://doi:10.1038/ s41598-018-20165-y

Liang J., Crowther T.W., Picard N., 2016. Positive biodiversity-productivity relationship predominant in global forests. Science 354(6309). https://doi. org/10.1126/science.aaf8957

MLUV, Natur Schutz Fonds, 2005. Braunerde 
[Brown soil]. Steckbriefe Brandenburger Böden. Ministerium für Ländliche Entwicklung, Umwelt und Verbraucherschutz. Potsdam, 4 p.

Marques C.P., 1991. Evaluating site quality of even-aged maritime pine stands in northern Portugal using direct and indirect methods. Forest Ecology and Management 41: 193-204. https://doi.org/10.1016/03781127(91)90103-3

Namikawa K., Okamoto S., Sano J., 2000. Edaphic controls on mosaic structure of the mixed deciduous broadleaf/conifer forest in northern Japan. Forest Ecology and Management 127: 169-179. https://doi. org/10.1016/S0378-1127(99)00128-0

Nilsson U., Elfving B., Karlsson K., 2012. Productivity of Norway spruce compared to Scots pine in the interior of Northern Sweden. Silva Fennica 46: 197-209. http:// www.metla.fi/silvafennica/full/sf46/sf462197.pdf

von Oheimb G., Härdtle W., Eckstein D., Engelke H-H., Hehnke T., Wagner B., Fichtner A., 2014. Does forest continuity enhance the resilience of trees to environmental change? Plos One 9(12): e113507. https://doi.org/10.1371/journal.pone.0113507

Olaczek R., 1976. Changes in the vegetation cover of Poland since the middle of XIX century. Zeszyty Problemowe Postępów Nauk Rolniczych 177: 369-408.

Operat glebowo siedliskowy. Nadleśnictwo Bolesławiec, Głogów, Oława [Soil and habitat survey. Bolesławiec, Głogów, and Oława forest inspectorates]. 2003, 2004, 2005. Operat s.c., Toruń.

Paquette A., Messier C., 2011. The effect of biodiversity on tree productivity: from temperate to boreal forests. Global Ecology and Biogeography 20: 170-180. https:// doi.org/10.1111/j.1466-8238.2010.00592.x

Pretzsch H., Block J., Dieler J., Dong P.H., Kohnle U., Nagel J., Spellmann H., Zingg A., 2010. Comparison between the productivity of pure and mixed stands of Norway spruce and European beech along an ecological gradient. Annal of Forest Science 67: 712. https://doi: $10.1051 /$ forest/2010037

Pretzsch H., del Rio M., Ammer C., Avdagic A., Barbeito I., Bielak K., ..., Bravo Oviedo A., 2015. Growth and yield of mixed versus pure stands of Scots pine (Pinus sylvestris L.) and European beech (Fagus sylvatica L.) analysed along a productivity gradient through Europe. European Journal of Forest Research 134: 927-947. https://doi: 10.1007/s10342-015-0900-4

Pritchett W.L., 1979. Properties and management of forest soils. John Wiley \& Sons, New York. 500 p.

Schelhaas M-J., Nabuurs G-J., Schuck A., 2003. Natural disturbances in the European forests in the 19th and 20th centuries. Global Change Biology 9: 1620-1633. https://doi: 10.1046/j.1365-2486.2003.00684.x

Sewerniak P., 2011. The influence of soil texture on site index of Scots pine stands in south-west Poland. Forest Research Papers 72: 311-319. https://doi:10.2478/ v10111-011-0031-8

Sewerniak P., 2012a. Impact of soil properties on site index class of Scots pine (Pinus sylvestris L.) stands in south-western Poland. I. pH, content of $\mathrm{CaCO}_{3}$ and properties concerning soil depth. Sylwan 156: 427-436. https://doi.org/10.26202/sylwan.2012025

Sewerniak P., 2012b. Impact of soil properties on site index class of Scots pine (Pinus sylvestris L.) stands in south-western Poland. II. Some chemical properties. Sylwan 156: 518-525. https://doi.org/10.26202/ sylwan.2012026

Sewerniak P., 2013. Site index of Scots pine stands in south-western Poland in relations to forest site types and soil units. Sylwan 157: 516-525. https://doi. org/10.26202/sylwan.2013028

Sewerniak P., 2016. Impact of land relief on site index and growth parameters of Scots pine stands on inland dunes in the Toruń Basin. Sylwan 160: 647-655. https://doi. org/10.26202/sylwan.2016056

Sewerniak P., Piernik A., 2012. Regression models for impact of soil properties on site index class of Scots pine (Pinus sylvestris L.) stands in south-western Poland. Sylwan 156: 563-571. https://doi.org/10.26202/ sylwan.2012043

Sharma M., Amateis R.L., Burkhart H.E., 2002. Top height definition and its effect on site index determination in thinned and unthinned loblolly pine plantations. Forest Ecology and Management 168: 163-175. https://doi. org/10.1016/S0378-1127(01)00737-X

Sharma R.P., Brunner A., Eid T., Oyen B.H., 2011. Modelling dominant height growth from national forest inventory individual tree data with short time series and large age errors. Forest Ecology and Management 262: 2162-2175. https://doi:10.1016/j.foreco.2011.07.037

Sheil D., Bongers F., 2020. Interpreting forest diversityproductivity relationships: volume values, disturbance histories and alternative inferences. Forest Ecosystems 7: 6. https://doi.org/10.1186/s40663-020-0215-x

Siedliskowe podstawy hodowli lasu, załącznik do Zasad hodowli lasu [Habitat basics of silviculture, appendix to the Principles of Silviculture]. Ośrodek RozwojowoWdrożeniowy Lasow Państwowych w Bedoniu, Warszawa.

Sierota Z., Grodzki W., Szczepkowski A., 2019. Abiotic and biotic disturbances affecting forest health in Poland over the past 30 years: impacts of climate and forest management. Forests 10(1): 75. https://doi.org/10.3390/f10010075

Skovsgaard J.P., Vanclay J.K., 2008. Forest site productivity: a review of the evolution of dendrometric concepts for even-aged stands. Forestry 81: 13-31. https://doi:10.1093/forestry/cpm041

Socha J., 2008. Effect of topography and geology on the site index of Picea abies in the West Carpathian, Poland. Scandinavian Journal of Forest Research 23: 203-213. https://doi: 10.1080/02827580802037901

Socha J., 2012. Long-term effect of wetland drainage on the productivity of Scots pine stands in Poland. Forest Ecology and Management 274: 172-180. https://doi. org/10.1016/j.foreco.2012.02.032

Socha J., Orzeł S., 2013. Dynamic site index curves for Scots pine (Pinus sylvestris L.) in southern Poland. Sylwan 157: 26-38. https://doi.org/10.26202/ 
sylwan.2012094

Socha J., Coops N.C., Ochal W., 2016. Assessment of age bias in site index equations. iForest Biogeosciences and Forestry 9: 402-408. https://doi:10.3832/ifor1548-008

Soil Survey Staff, 2014. Keys to soil taxonomy, 12th ed. USDA Natural Resources Conservation Service, Washington, DC.

Spiecker H., 2003. Silvicultural management in maintaining biodiversity and resistance of forests in Europe-temperate zone. Journal of Environmental Management 67: 55-65. https://doi.org/10.1016/S03014797(02)00188-3

Systematyka gleb Polski, wyd. 6, 2019. Wyd. UP we Wrocławiu, INoGiOŚ UP we Wrocławiu, PTG. Kom. Genezy, Klasyfikacji I Kartografii Gleb, WrocławWarszawa.

Wang J., You Y., Tang Z., Liu S., Sun O.J., 2014. Variations in leaf litter decomposition across contrasting forest stands and controlling factors at local scale. Journal of Plant Ecology 8: 261-272. https://doi.org/10.1093/jpe/rtu019

Zerbe S., 2002. Restoration of natural broad-leaved woodland in Central Europe on sites with coniferous forest plantations. Forest Ecology and Management 167: 27-42. https://doi.org/10.1016/S0378-1127(01)00686-7

Zhang J., Lyu Z., Shao S., Li F., Yang S., Song W., Li W., Li S., 2016. Effects of aluminium toxicity induced by acid deposition on pine for-est Ecosystem in Longli of Guizhou Province, Southwestern China. Chinese Geographical Science 26: 495-507. https://doi: 10.1007/ s11769-015-0763-0

Zhang Y., Chen H.Y.H., Reich P.B., 2012. Forest productivity increases with evenness, species richness and trait variation: a global meta-analysis. Journal of Ecology 100: 742-749. https://doi:10.1111/j.13652745.2011.01944.x

Zhang Y., Chen H.Y.H., Taylor A.R., 2017. Positive species diversity and above-ground biomass relationships are ubiquitous across forest strata despite interference from overstorey trees. Functional Ecology 31: 419-426. https://doi: 10.1111/1365-2435.12699

Zhou G., Guan L., Wei X., Tang X., Liu S., Liu J., Zhang D., Yan J., 2008. Factors influencing leaf litter decomposition: an intersite decomposition experiment across China. Plant and Soil 311: 61-72. https://doi: 10.1007/s11104-008-9658-5

Zhu J.J., Fan Z.P., Zeng D.H., Jiang F.Q., Matsuzaki T., 2003. Comparison of stand structure and growth between artificial and natural forests of Pinus sylvestris var. mongolica on sandy land. Journal of Forestry Research 14: 103-111. https://doi.org/10.1007/ BF02856774 